\title{
A Developmental Staging Table for Physalaemus biligonigerus (Cope, 1861) (Anura: Leptodactylidae)
}

\author{
Mariana Chuliver ${ }^{1, *}$, Marissa Fabrezi ${ }^{1}$ \\ ${ }^{1}$ Instituto de Bio y Geociencias del NOA, Consejo Nacional de Investigaciones Científicas y Técnicas, Rosario de Lerma, Salta, Argentina. \\ * Corresponding author. Email: marianachp@yahoo.com.ar
}

\begin{abstract}
Physalaemus biligonigerus is a leptodactylid frog that is widely distributed in southern South America and a common member of anuran assemblages that breed in temporary ponds near human settlements. Herein, we analyzed its embryonic and larval morphology through the completion of metamorphosis and constructed a normal table of development. In addition, the timing of development and growth data are provided. Development of P. biligonigerus from fertilization through metamorphosis takes 20-24 days. We recognized 46 discrete developmental stages on the basis of readily discerned, unambiguous, external traits that can be identified in preserved specimens. In contrast with the standard Gosner developmental table, we recognized several particularities in the development of this species. The staging criterion based on external gill morphology presented here is a novel approach to distinguish pre- and post-hatching stages, which could also be employed in other anuran species. We found that anal tube loss in P. biligonigerus occurs earlier than Gosner Stage 41; this trait is highly variable among species and should not be used as a standard criterion. Our analysis demonstrates the value of detailed specific staging tables to characterize anuran life cycles. Furthermore, we point out that the use of generalized standard tables might mask the richness of phenotypic variation during the ontogeny of anuran species.
\end{abstract}

Keywords. Development; Growth; Leptodactylid; Morphology; Ontogeny.

\begin{abstract}
Resumen. Physalaemus biligonigerus es un leptodactílido ampliamente distribuido en el sur de Sudamérica y un miembro común de los ensambles de anuros que se reproducen en charcas temporales cerca de asentamientos humanos. En este estudio analizamos su morfología embrionaria y larval hasta el fin de la metamorfosis y construimos una tabla normal de desarrollo. Además, proporcionamos el tiempo de desarrollo y datos sobre crecimiento. El desarrollo de P. biligonigerus, desde la fertilización hasta el fin de la metamorfosis dura 20-24 días. Reconocimos 46 estadios discretos basados en rasgos fácilmente discernibles y no ambiguos de la morfología externa, los cuales pueden ser identificados en especímenes preservados. En contraste con la tabla de desarrollo estándar de Gosner, se reconocen varias particularidades en el desarrollo de esta especie. El criterio de estadificación basado en la morfología de las branquias externas aquí presentado representa una forma novedosa de distinguir las etapas pre- y post-eclosión, que podría emplearse en otras especies de anuros. Encontramos que la pérdida del tubo anal en P. biligonigerus ocurre antes del estadio 41 de Gosner; este carácter es altamente variable entre especies y no debería considerarse como un criterio estándar. Nuestro análisis demuestra el valor de tablas específicas y detalladas para caracterizar los ciclos de vida de anuros. Además, señalamos que el uso de tablas estándar generalizadas podría enmascarar la riqueza de la variación fenotípica durante la ontogenia de las especies de anuros.
\end{abstract}

\section{INTRODUCTION}

Most anurans are characterized by a biphasic life cycle, with two important processes of morphological changes. The first occurs between embryonic and larval stages, whereas the second occurs between the larval stage and adulthood (Duellman and Trueb, 1994). The change from egg to larva and from tadpole to adult needs to be well documented if one wants to compare ontogenesis between taxa. This requires an effective method to organize the progress of development (Dünker et al., 2000); therefore, the developmental tables are the most useful tool to order developmental events (e.g., Shumway, 1940; Taylor and Kollros, 1946; Limbaugh and Volpe, 1957; Schreckenberg and Jacobson, 1975; Sammouri et al., 1990; Iwasawa and Yamashita, 1991; Nieuwkoop and Faber, 1994; Shi and Boucaut, 1995; Hall et al., 1997; Dünker et al., 2000; Fabrezi et al., 2009, Fabrezi et al., 2012). Accordingly, documenting variation in development and growth is important for understanding general developmental patterns and for detecting divergence processes in the ontogenesis that can resolve systematic relationships (Hall et al., 1997).

The external and generally rapid development of anurans facilitates the study of their life cycles. Consequently, data on developmental time in captivity or even in the field are relatively easy to obtain. Despite these advantages, developmental tables are available for fewer than 120 species, which represent less than $2 \%$ of the extant anuran diversity (Fabrezi et al., 2017). Moreover, knowledge about morphological variation during anuran de-

How to cite this article: . South American Journal of Herpetology 14:150-161. http://doi.org/10.2994/SAJH-D-18-00005.1 
velopment is generally characterized on the basis of just a few standardized tables (i.e., Taylor and Kollros, 1946; Gosner, 1960; Nieuwkoop and Faber, 1994). Using these generalized tables neglects much interspecific variation in larval development and growth that may have had consequences in anuran diversification (Fabrezi, 2011).

We present here a detailed description of the embryonic and larval development of the leptodactylid frog Physalaemus biligonigerus (Cope, 1861), together with a staging table based on external morphological characters that synthesize the species development through the end of metamorphosis. We also provide species-specific features and data on developmental time and growth to facilitate comparison among populations and detect anatomical anomalies in the context of rapid environmental changes. Our results will also facilitate comparison of developmental patterns with other leptodactylid genera (e.g., Pleurodema Tschudi, 1838, Leptodactylus Fitzinger, 1826).

Physalaemus biligonigerus is distributed in northern and central Argentina, adjacent Bolivia, Paraguay, Uruguay, and southern Brazil (Fig. 1A; Frost, 2018). Adults are small to medium-sized, terrestrial, and sexually dimorphic. They have a conspicuous advertisement call and

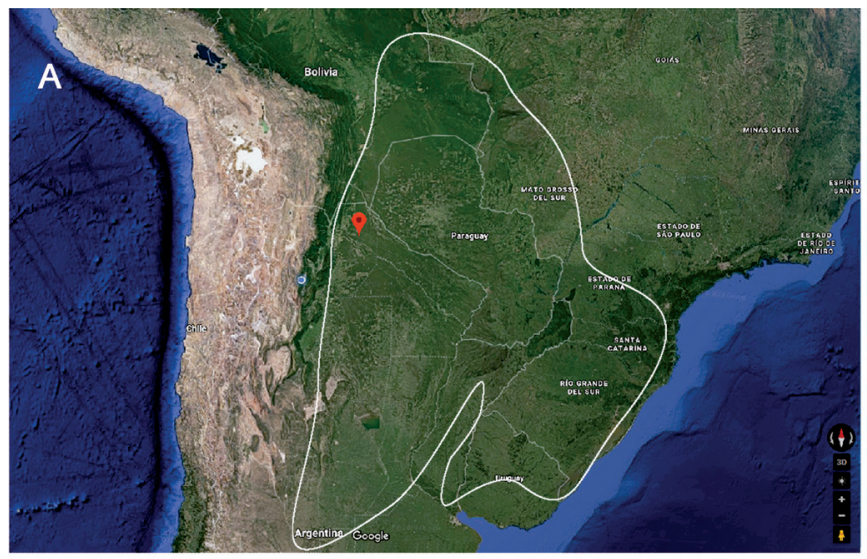

reproduce during the warm, rainy season in temporary ponds near human settlements, even in highly disturbed environments like soybean fields. During amplexus the male uses his legs to beat the albuminous secretion with eggs released by the female, forming a mass of white foam that is placed near vegetation on the shore of the ponds (Cei, 1980). Foam nests contain approximately 1,0501,690 eggs (Zaracho et al., 2005), and tadpoles are type IV according to Orton's (1953) classification.

Phylogenetic hypotheses for the species of Physalaemus Fitzinger, 1826 have been proposed in recent analyses of molecular data (Pyron and Wiens, 2011; Lourenço et al., 2015). Lourenço et al. (2015) recognized the $P$. biligonigerus species group, composed of $P$. biligonigerus, P. marmoratus (Reinhardt and Lütken, 1862), P. santafecinus Barrio, 1965, and P. riograndensis Milstead, 1960. Tadpoles of these four species share a similar oral disc morphology, which is characterized by the presence of two lower labial tooth rows. This might be a synapomorphy of these species (Lourenço et al., 2015) and defines an oral disc that truncates its development with regard to the plesiomorphic 2/3 larval labial tooth-row formula (Vera Candioti et al., 2011).

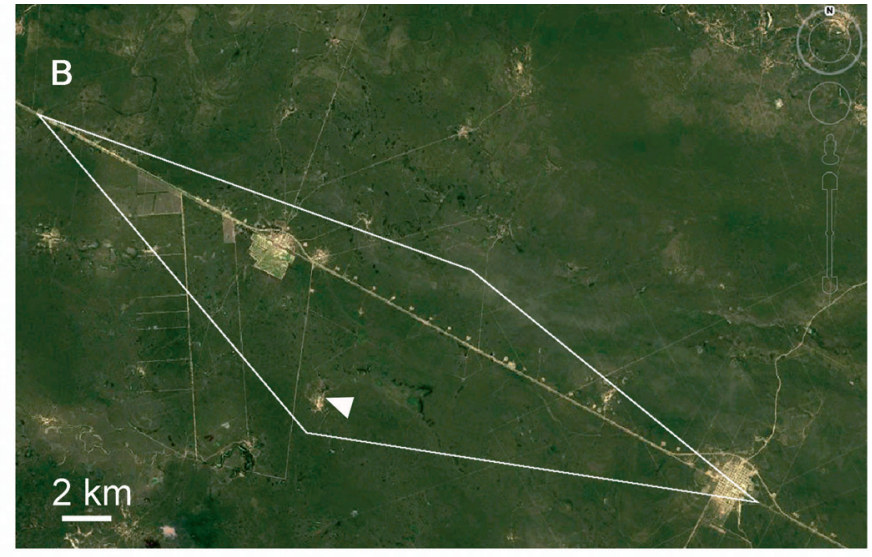

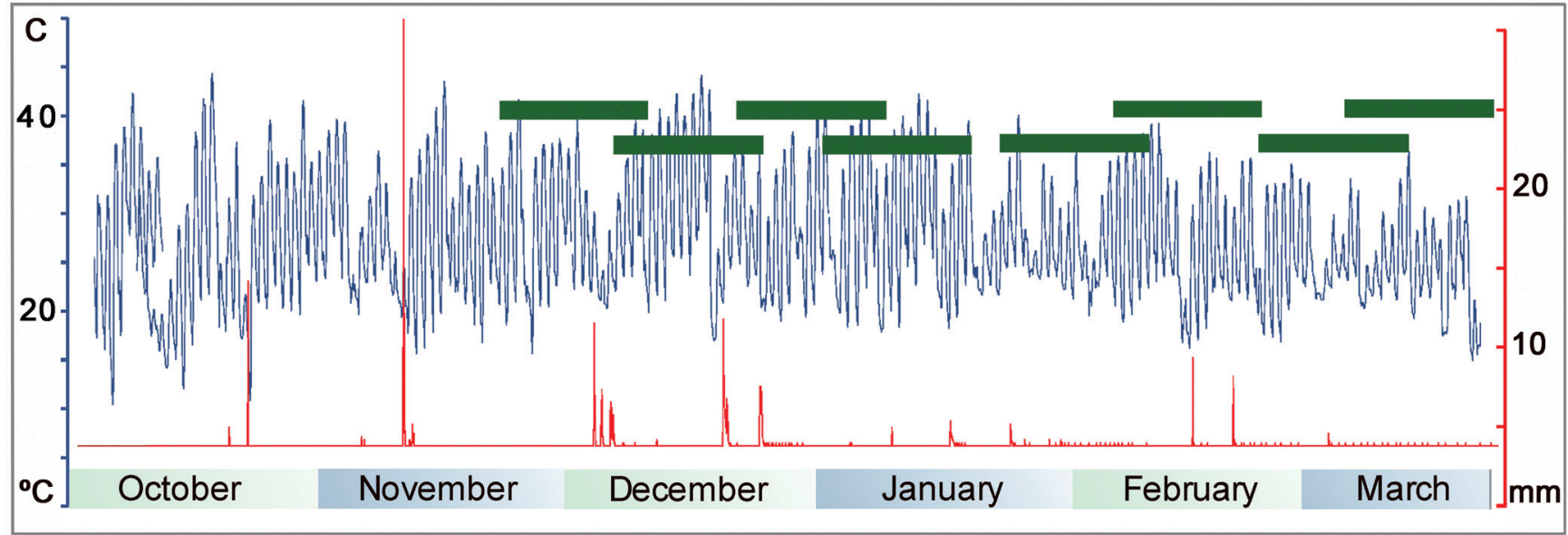

Figure 1. (A) Satellite image of southern South America showing Physalaemus biligonigerus distribution. The red mark indicates the locality of our study area. (B) Detail of the study area. The polygon delimits the area where field records of $P$. biligonigerus were taken. White arrow points the localization of a semi-automatic weather station. (C) Climatic diagram with temperature $\left({ }^{\circ} \mathrm{C}\right.$; left axis) and rain ( $\mathrm{mm}$; right axis) records from October 2017 to March 2018. Green bars depict the presence of tadpoles of different age groups of $P$. biligonigerus over the summer. 
Table 1. Synopsis of the diagnostic features defining stages in the embryonic and larval development of Physalaemus biligonigerus. Developmental time is given for Stages $1-26$. Values are reported as $\bar{X} \pm S D$.

\begin{tabular}{|c|c|c|c|}
\hline Stage & Diagnostic features & Total length (mm) & Time (h) \\
\hline 1 & 1 cell, smooth eggs, pigmentation absent & $1 \pm 0.05$ & 0 \\
\hline 2 & 2 cells divided by complete cleavage furrow (meridional) & $1 \pm 0.05$ & $1 \pm 0.35$ \\
\hline 3 & 4 cells, embryo divided by second cleavage furrow (meridional) & $1 \pm 0.05$ & $2 \pm 0.35$ \\
\hline 4 & $\begin{array}{l}8 \text { cells, embryo divided by third furrow (supraequatorial), four micromeres in animal pole and four } \\
\text { macromeres in vegetative pole }\end{array}$ & $1 \pm 0.05$ & $2.5 \pm 0.35$ \\
\hline 5 morula & 16 cells, embryo divided by fourth and fifth cleavage furrows (meridional) & $1 \pm 0.05$ & $3.33 \pm 0.35$ \\
\hline 6 morula & 32 cells, embryo divided by the sixth cleavage furrow (supra-equatorial) & $1 \pm 0.05$ & $4 \pm 0.35$ \\
\hline 7 blastula & Numerous, large, and well-defined cells, resulted from multiple and disorganized cleavage furrows. & $1 \pm 0.05$ & $5 \pm 0.35$ \\
\hline 8 blastula & Numerous tiny cells of subequal size & $1 \pm 0.05$ & $7 \pm 0.35$ \\
\hline 9 & Dorsal lip of blastopore as a crescent-shaped slit in the vegetative pole & $1 \pm 0.05$ & $10 \pm 1.5$ \\
\hline 10 gastrulae & $\begin{array}{l}\text { Lateral and ventral lips of the blastopore enclosing rounded yolk plug, its diameter approximately } \\
\text { equal to } 1 / 2 \text { diameter of embryo (i.e., } 0.5 \mathrm{~mm} \text { ) }\end{array}$ & $1 \pm 0.05$ & $12 \pm 1.5$ \\
\hline 11 gastrulae & Yolk plug diameter $1 / 4$ of diameter of embryo (i.e., $0.25 \mathrm{~mm}$ ) & $1 \pm 0.05$ & $15 \pm 1.5$ \\
\hline 12 gastrulae & Yolk plug diameter $<1 / 4$ of diameter of embryo; embryo ovoid & $1 \pm 0.05$ & $17 \pm 1.5$ \\
\hline 13 neurula & $\begin{array}{l}\text { znterior and dorsal regions of embryo denoted by broad anterior plate (neural plate) and pair of } \\
\text { short neural folds }\end{array}$ & $1.25 \pm 0.05$ & $20 \pm 1.5$ \\
\hline 14 neurula & Neural folds elevated, defining deep groove (neural groove); embryo lengthens & $1.25 \pm 0.05$ & $23 \pm 1.5$ \\
\hline 15 neurula & Neural folds contact in the mid-dorsal surface; ventral yolk mass with uniform appearance & $1.5 \pm 0.05$ & $26 \pm 1.5$ \\
\hline 16 & $\begin{array}{l}\text { Anterior region with ventral depression (stomodeum) and short tail bud with rounded end defining } \\
\text { cephalic and caudal regions, respectively. }\end{array}$ & $1.5 \pm 0.05$ & $31 \pm 2.5$ \\
\hline 17 & $\begin{array}{l}\text { Adhesive }(=\text { cement) glands on both sides of stomodeum, bulges of gill buds and eyes in cephalic } \\
\text { region, pronephros protuberances in mediolateral position, anal tube in posteroventral region }\end{array}$ & $1.5 \pm 0.05$ & $35 \pm 2.5$ \\
\hline 18 & Spherical and prominent gill buds, tail with dorsal and ventral fins outlined & $1.75 \pm 0.08$ & $40 \pm 3$ \\
\hline 19 & $\begin{array}{l}\text { Each gill bulge divided into } 2 \text { lobes by medial groove (first and second gill arches), anterior lobe } \\
\text { divided in } 2 \text { filaments }\end{array}$ & $2 \pm 0.09$ & $47 \pm 3$ \\
\hline 20 & First gill with 2-3 filaments, second gill divided into 2 lobes. & $2.25 \pm 0.12$ & $54 \pm 3$ \\
\hline 21 & First gill with $4-5$ filaments, second gill with 3 filaments & $2.5 \pm 0.13$ & $59 \pm 3$ \\
\hline 22 & First gill with 5-6 filaments, second gill with 4 filaments & $2.5 \pm 0.18$ & $65 \pm 3$ \\
\hline 23 & First gill with 6-7 filaments, second gill with 5 filaments & $3.25 \pm 0.17$ & $75 \pm 4$ \\
\hline 24 & First gill with 7-8 filaments, second gill with 6 filaments, nostrils and mouth differentiated & $4.25 \pm 0.23$ & $82 \pm 4$ \\
\hline 25 & Second gill with 7 filaments; oral disc with upper and lower lips & $5.25 \pm 0.23$ & $120 \pm 8$ \\
\hline 26 & Oral disc with keratinized parts, operculum covering external gills partially or totally & $6.25 \pm 0.25$ & $150 \pm 8$ \\
\hline 27 & Hind limb bud length $\geq 1 / 2$ diameter & $10.75 \pm 1.5$ & \\
\hline 28 & Hind limb bud length $\geq$ diameter & $12.1 \pm 0.96$ & \\
\hline 29 & Hind limb bud length $\geq 1.5 \times$ diameter & $14.4 \pm 1.1$ & \\
\hline 30 & Hind limb bud length $\geq 2 \times$ diameter & $14.9 \pm 1.65$ & \\
\hline 31 & Hind limb bud paddle-shaped (autopodium with anterior and posterior indentations) & $15.4 \pm 1.4$ & \\
\hline 32 & Autopodium asymmetrical with distal and postaxial elongation of primary axis (Toe IV) & $16.3 \pm 1.4$ & \\
\hline 33 & $\begin{array}{l}\text { Toes IV and V extended beyond autopodium boundaries, separated by indentations; estilopodium } \\
\text { and zeugopodium differentiated }\end{array}$ & $16.6 \pm 2.9$ & \\
\hline 34 & Indentation defining Toe III & $17.8 \pm 3.5$ & \\
\hline 35 & Indentations defining Toes I and II & $22.1 \pm 1.6$ & \\
\hline 36 & Toes IV and V separated and elongate, tarsus and pes differentiated & $24.8 \pm 2.1$ & \\
\hline 37 & $\begin{array}{l}5 \text { toes elongated and separated without interdigital tissue; ventrally, both hind limbs completely } \\
\text { separated by anal tube }\end{array}$ & $26.2 \pm 2.1$ & \\
\hline 38 & Anterior and posterior metatarsal tubercles & $26.9 \pm 2.5$ & \\
\hline 39 & Digital subarticular tubercles, anal tube dorsal to hind limbs & $28.9 \pm 2.2$ & \\
\hline 40 & Tarsal tubercle, fibers of $M$. rectus abdominis visible in the ventral body wall & $28.6 \pm 5.1$ & \\
\hline 41 & Oral disc without keratinized teeth, upper eyelid. & $28.8 \pm 4.6$ & \\
\hline 42 & $\begin{array}{l}\text { Both forelimbs emerged fully formed, lower eyelid and nictitating membrane, oral disc without } \\
\text { keratinized parts }\end{array}$ & $25.6 \pm 3.7$ & \\
\hline 43 & Mouth commissure between the nares and anterior margin of eye & $20.5 \pm 4.5$ & \\
\hline 44 & $\begin{array}{l}\text { Mouth commissure prior to the anterior half of the eye, tail atrophied, with markedly different skin } \\
\text { coloration, ventral fin lost, and dorsal fin reduced }\end{array}$ & $11.9 \pm 5.4$ & \\
\hline 45 & $\begin{array}{l}\text { Mouth commissure exceeding anterior half of eye, tail forming prominence with same color as skin } \\
\text { of dorsal body }\end{array}$ & $10.9 \pm 1.8$ & \\
\hline 46 & Complete tail loss, mouth commissure reaching posterior limit of eye & $13.4 \pm 1.1$ & \\
\hline
\end{tabular}




\section{MATERIALS AND METHODS}

To describe embryonic stages, eight amplectant pairs were collected around Salta city $\left(24^{\circ} 45^{\prime} 28^{\prime \prime}\right.$, $\left.65^{\circ} 27^{\prime} 48^{\prime \prime} \mathrm{W}\right)$, Argentina, in January and February 2014, 2015 , and 2016. Each mating pair was kept in plastic containers with pond water until foam nests were obtained. The clutches were kept at ambient temperature and exposed to a natural light cycle. From two foam nests, we extracted samples every hour during the first $12 \mathrm{~h}$ and every $2 \mathrm{~h}$ until the larvae started feeding. From the remaining six foam nests, we took samples 36 and $48 \mathrm{~h}$ after fertilization (three foam nests each) every $2 \mathrm{~h}$ until the larvae started feeding. The number of individuals varied in each sample but included at least 20 per sample to establish developmental stages.

Descriptions of larval and metamorphic stages were based on individuals collected between 1998-2014 in Salta Province (Appendix). Additionally, we collected tadpoles from November 2017 to April 2018 in temporary ponds in a polygon comprising the coordinates $23^{\circ} 26^{\prime} 18.30^{\prime \prime} \mathrm{S}, 63^{\circ} 4^{\prime} 44.46^{\prime \prime} \mathrm{W}$, where a semiautomatic weather station was installed (Fig. 1B).

Embryos and larvae were fixed in $10 \%$ formalin with $0.5 \%$ acetic acid. Fixed embryos were freed with forceps from the surrounding egg membranes and measured with the aid of a stereomicroscope. Body length and total length were measured with a caliper accurate to $0.25 \mathrm{~mm}$. The total length of embryos was measured as the straightline distance between the two furthest points in lateral view, while the total length of larvae was assessed as the straight-line distance between the tip of the snout and tip of the tail. Observations and photographs were made using a trinocular stereomicroscope Nikon with digital camera.

We defined the commencement of development by the appearance of egg clutches, thus indicating fertilization $\left(t_{0}\right)$. The developmental time given in Table 1 is that required for at least $75 \%$ of the sample to reach a particular stage. We used at least 20 individuals per sample to establish their developmental timing. We used foam nests maintained in the laboratory to estimate developmental timing from fertilization to larval pre-feeding stages. To estimate developmental time for larval and metamorphic stages, we employed individuals collected from one small pond formed after a rainstorm, which was sampled every $5 \mathrm{~d}$ for three consecutive weeks.

All specimens are deposited in the Herpetological Collection of the Instituto de Bio y Geociencias del NOA (IBIGEO) and are listed in the Appendix. The terminology used to describe Physalaemus biligonigerus development was that used in developmental tables for Incilius valliceps (Wiegmann, 1833) (Gosner, 1960) and Xenopus laevis (Daudin, 1802) (Nieuwkoop and Faber, 1994) to simplify comparisons with those and other species.

\section{RESULTS}

We recognize 46 discrete developmental stages for Physalaemus biligonigerus from fertilization through the end of metamorphosis on the basis of readily discernible and unambiguous external morphological features. Fertilized eggs are embedded in a white foam nest (Fig. 2A). Each egg is uniformly white and surrounded by a transparent gelatinous capsule (Fig. 2B). When the eggs are free from their capsules, their average diameter is $1 \mathrm{~mm}$ $(\mathrm{SD}=0.05 \mathrm{~mm} ; n=25)$. Fertilization is not evident until the first cleavage furrow appears. From fertilization to the end of gastrulation, embryos do not exhibit macroscopic changes in diameter or coloration (Fig. 2C-H). Cleavage is holoblastic and cell boundaries are well distinguished and rounded. We defined Stage 4 by the presence of four macromeres (vegetative pole) and micromeres (animal pole) with minor size differences between them. The 32 cell-stage (Stage 6) is reached $4 \mathrm{~h}$ after fertilization. Each new cleavage furrow appears on average every $40 \mathrm{~min}$. After these stages, cleavage furrows become asymmetri$\mathrm{cal}$ and differences between blastula stages (Stages 7-8) are evidenced by number, size, and organization of cells (Fig. 2D). At Stage 8, embryos acquire an externally compact appearance due to the homogenization and reduction of cell size. Cleavage is completed in 6-7 h. During gastrulation (Stages 9-12) the anteroposterior axis is defined; cells in the rounded yolk plug are polygonal and larger than those located outward of the plug (Fig. 2E-H).

The dorsoventral axis is defined during neurulation (Stages 13-15) by the formation of the neural plate in the anterior region and the neural folds in the dorsomedial region (Fig. 2I). At Stage, 15 the embryo acquires a semicircular shape with ventral yolk mass. Stage 16 is defined by the appearance of the tail bud while in the subsequent stage (Stage 17) external gill bulges appear (Fig. 2J-K). For Stages 19-25, the number of branches in the second pair of gills is indicative of the stage. The gill developmental trajectory between Stages 19-24 is summarized in Figure 3. During these stages, segmentation of the axial musculature is observed, adhesive glands develop, the tail bud lengthens, and dorsal and ventral fins grow progressively in height (Fig. 2M-S).

The developmental stage in which hatching occurs in Physalaemus biligonigerus varies. Development in the foam nest lasts on average $62 \pm 3 \mathrm{~h}$. Some embryos hatch at Stage 21 after $59 \mathrm{~h}$, while others hatch after $65 \mathrm{~h}$ when their external gill development is more advanced (i.e., at Stage 22). Upon hatching, embryos release their egg membranes and fall into the water where they are able to make moderate movements. However, at this stage tadpoles do not feed. At Stage 22, melanophores appear in the dorsal region of head and body, with pigmentation increasing through Stages 23-26 to cover the dorsal region of the head and body as well as the eye formation 

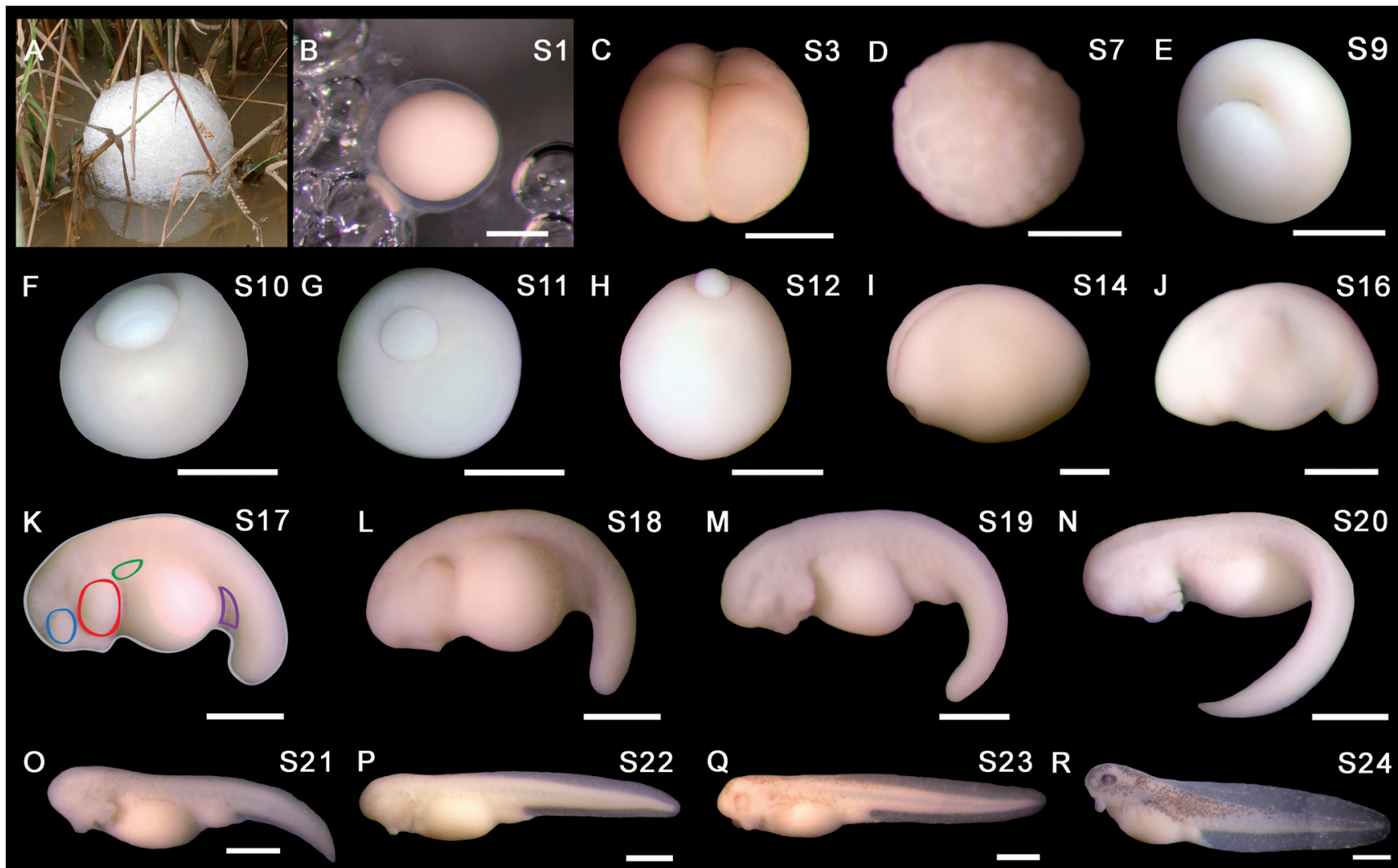

S24
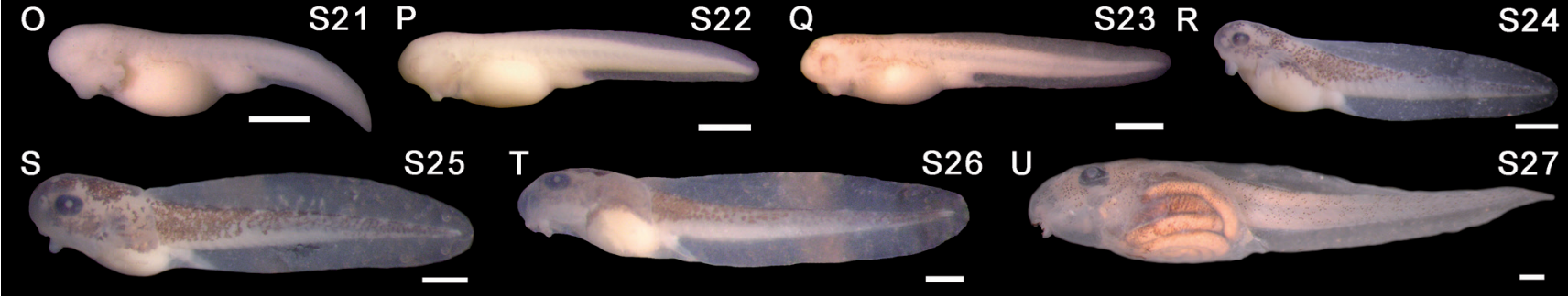

Figure 2. External view of embryos and larvae of Physalaemus biligonigerus, from cleavage to first feeding stage. (A) Foam nest; (B) egg within the foam nest; (C) four-cell stage; (D) large-cell blastula; (E) early gastrula, dorsal lip of blastopore as crescent-shaped slit; (F) gastrula, lips of blastopore enclosing yolk plug; (G) late gastrula, yolk plug diameter 25\% of diameter of embryo; (H) late gastrula with small yolk plug; (I) embryo showing formation of neural groove; (J) tail bud embryo; (K) stage with bulges outlined in different colors, eyes (blue), gills (red), pronephros (green), and future anal tube zone (violet); (L) stage with spherical and prominent gill buds; (M-T) Stages 19-25, during which segmentation of the axial musculature is observed, adhesive glands develop, tail lengthens, dorsal and ventral fins grow in height, and pigmentation progresses; (U) hind limb bud larvae. Stages indicated by codes S1-S27. Scale bars $=0.5 \mathrm{~mm}$.

area (Fig. 2Q-T). The body shape becomes ovoid, the tail doubles its length, and dorsal and ventral fins increase in height during Stages 23-26 (Fig. 2R-T). The eyeball is defined at Stage 24 (Fig. 2R). At Stage 25 the mouth opening (stomodeum) is oval with sharp edges and upper and lower lips outline the oral disc, which does not exhibit keratinized structures (Fig. 4A). Adhesive discs are developed on both sides of the mouth. The maximum number of gill filaments is reached at Stage 25. The operculum starts developing at that stage and completely covers the gills in Stage 26 (Fig. 4B). Progress in the development of the operculum is asymmetrical, with the right external gills being covered first and the left gills still protruding in some individuals at this stage (Fig. 4B). The ventral body wall is translucent since no yolk remains, and the coiled intestine is visible.

Tadpoles of Physalaemus biligonigerus from Stage 27 to 40 have an ovoid body shape in dorsal and ventral views and their snouts rounded, with eyes and nostrils in a dorsal position (Fig. 5A). The oral disc is small and anteroventral with two anterior (A1-A2) and two posterior (P1$\mathrm{P} 2$ ) tooth rows. The labial tooth row formula is 2(2)/2(1); the gap in A2 is wider than that of P1 (Fig. 5B). Marginal papillae are subconical with rounded tips and occur along the entire ventrolateral margin with a gap dorsally (Fig. 5B). The upper jaw sheath is arched and overlaps the lower jaw sheath, which is V-shaped. Both jaws are finely serrate and brownish. The oral disc shows all the diagnostic characteristics of the species at Stage 27, which are maintained until Stage 40. The spiracle is short, sinistral, and directed posterodorsally at mid-body; its opening is oval, with a diameter approximately equal to the length of the tube (Fig. 5C). The anal tube is short and continuous with the ventral tail fin and its opening is slightly dextral (Fig. 5D). Both the spiracle and anal tube preserve their morphology until Stage 40 . The caudal musculature is 


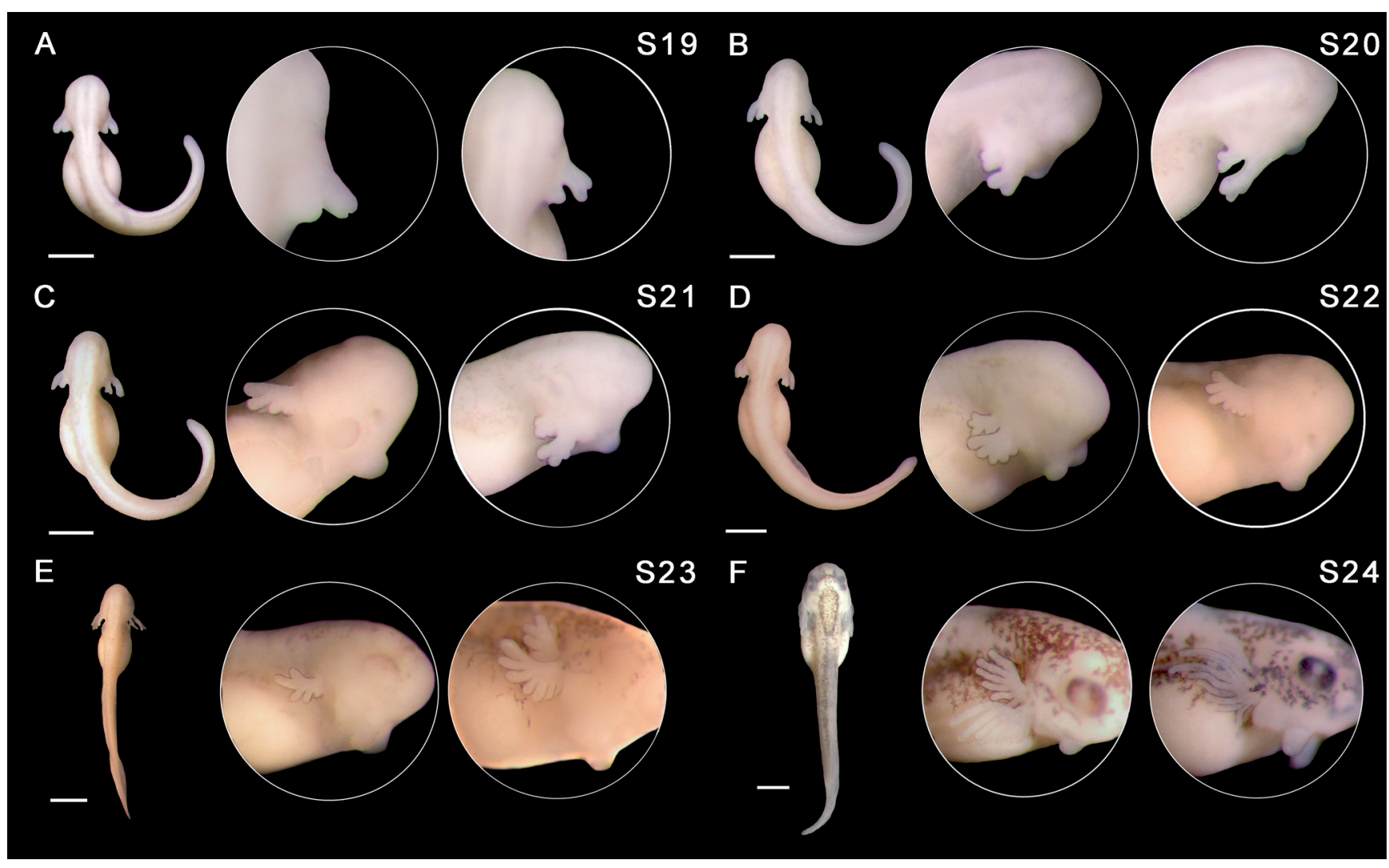

Figure 3. Representation of development of external gills of Physalaemus biligonigerus during Stages 19-24. The first pair of gills has two states (i.e., number of filaments) within the same stage. (A) Gill bulges divided into two lobes by a medial groove; at the end of the stage the groove between the lobes becomes deeper, with the anterior-most lobe divided into two filaments by a small distal commissure; (B) each lobe lengthens and subdivides forming filaments; (C-F) the number of gill filaments increases and lengthens in each stage. Stages indicated by codes S19-S24. Scale bars $=1 \mathrm{~mm}$.

moderately robust (Fig. 5A). The dorsal and ventral fins are transparent with discrete groups of melanophores. The dorsal fin extends briefly over the body and is slightly higher than the ventral fin (Fig. 5A).

The hind limb buds appear at Stage 27 (Fig. 2U). Identification of Stages 27-30 is based on the limb bud length/diameter ratio, following the same criteria proposed by Gosner (1960; Fig. 6). At Stage 31 the hind limb bud is paddle-shaped and Stages 32-35 are identi-

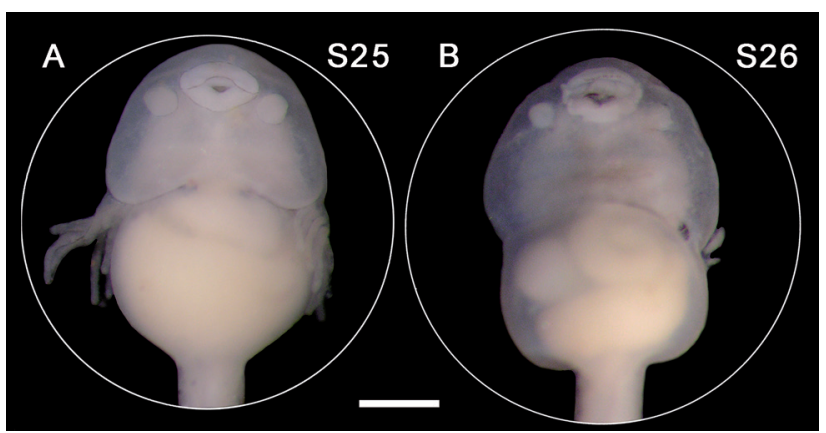

Figure 4. Physalaemus biligonigerus in Stages 25 and 26. (A) Ventral view of larval body at Stage 25; (B) ventral view of larval body at Stage 26 , characterized by external gills covered by the operculum and keratinized structures in the oral disc. Stages indicated by codes $S 25$ and S26. Scale bars $=0.5 \mathrm{~mm}$. fied by appearance of notches in the distal region of the hind limb, which indicates the successive delimitation of toes (Fig. 6B-D). Differentiation of segments in the hind limb occurs at Stages 31, 33, and 36 (Fig. 6B-C, E). Slight pigmentation distributed as dots on the dorsum of the limb appears at Stage 34 (Fig. 6D). Pigmentation then progresses towards the autopodial ventral surface (Stage 38). The anal tube is constricted as a result of the approximation of the hind limbs towards the body mid-

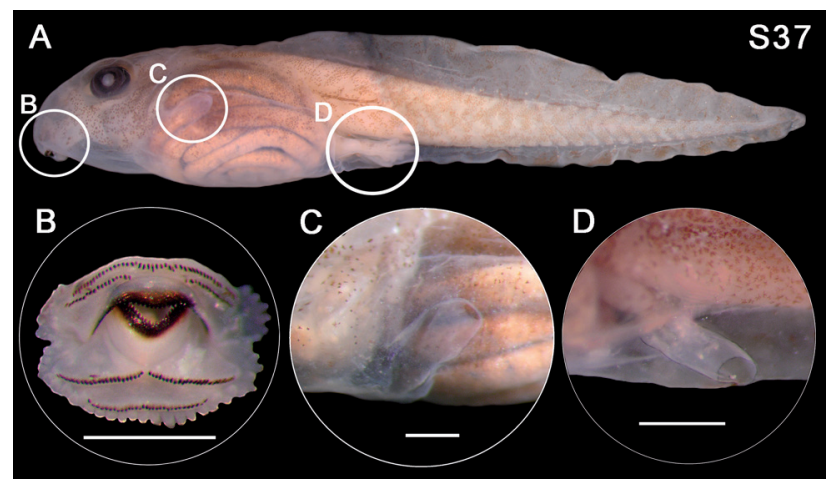

Figure 5. (A) Lateral view of general larval body aspect of Physalaemus biligonigerus at Stage 37 (S37) with oral disc, spiracle, and anal tube indicated by circles. (B) Oral disc; (C) Spiracle; (D) Anal tube (hind limb removed for better visualization). Scale bars $=0.5 \mathrm{~mm}$. 


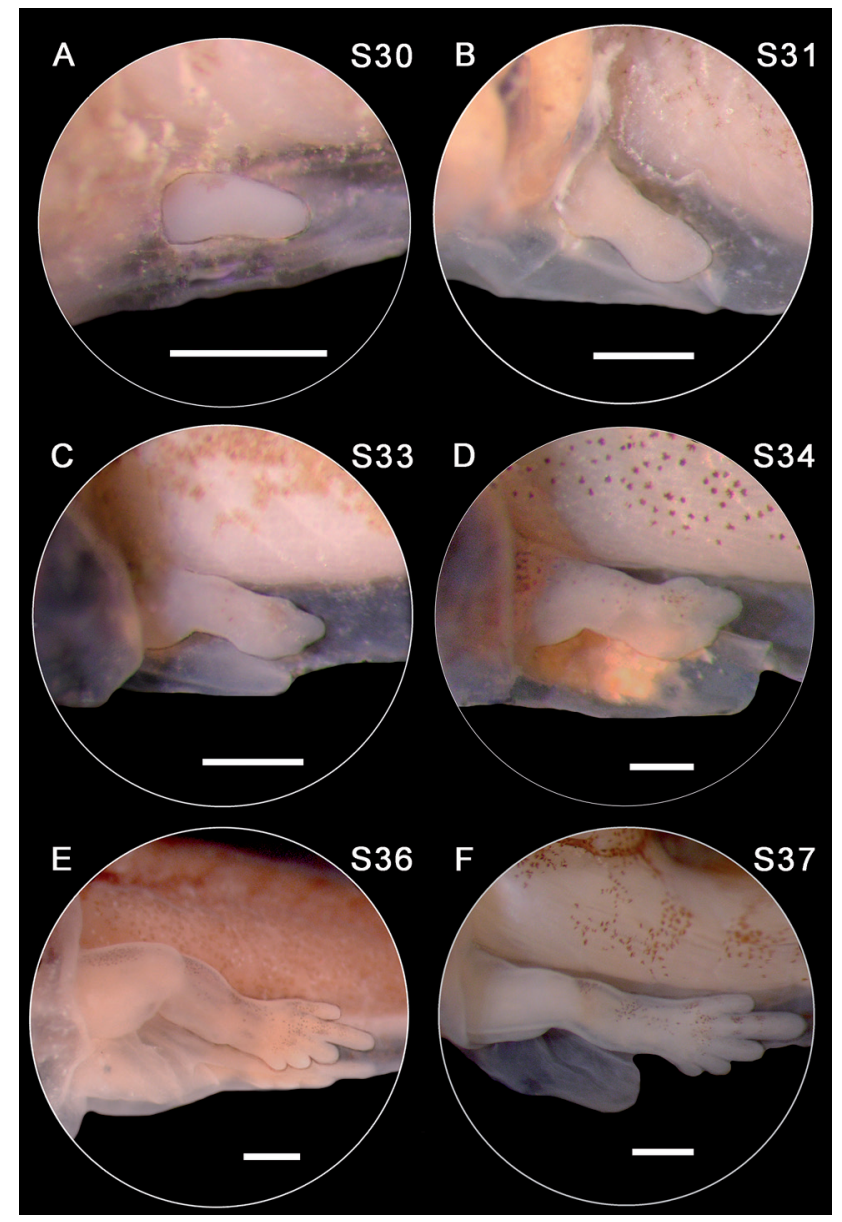

Figure 6. Development of the left hind limb of Physalaemus biligonigerus through Stages 30-37. Stages indicated by codes S30-S37. (A) Hind limb bud length more than twice its diameter. (B) Hind limb bud paddle-shaped. (C) Stylopodium and zeugopodium differentiated, Toes IV and V separated by indentations. (D) Toe III defined. (E) Tarsus and pes differentiated. (F) Five toes separated without interdigital tissue. Scale bars $=0.5 \mathrm{~mm}$.

line at Stage 38. At Stage 39 the hind limbs are proximally united as a consequence of the fusion of the pelvic girdles at the body midline, so the anal tube is no longer connected with the ventral skin (Fig. 7A). Stage 41 is characterized by changes in the oral disc, the first of which is loss of keratodonts (Fig. 7C). The ventral body wall becomes opaque and thicker by the progress in development of the rectus abdominis muscle. The thighs become robust and the autopodial tubercles are prominent and pointed.

Forelimbs emerge at Stage 42 (Fig. 8A), the left one first, through the spiracle opening, and then the right one. The forelimb skin is rapidly incorporated into the body's integument. The anal opening is observed but the skin of the anal tube remains attached to the ventral fin. Stages $43-45$ are primarily identified by the position of the mouth commissure relative to the eye and nostril in lateral view, as well as the degree of tail reduction (Fig. 8B-D). At Stage 43 the tail is at least 30\% shorter than at Stage 42, but it retains its general shape; both the dorsal and ventral fins decrease in height proximodistally, but the dorsal fin remains taller (Fig. 8B). Metamorphosis is completed at Stage 46 when the tail is fully resorbed (Fig. 8E). The transformed froglet has certain features of the adult, such as a tarsal tubercle and the pattern of bands on the limbs; however, it lacks other adult traits, such as the lumbar glands.

In ponds of the Chacoan environment within the polygon where we have made collections, we found adults of Physalaemus biligonigerus reproducing throughout the austral summer (Fig. 1C). Mating can occur many times in the same pond; hence, we found up to eight age groups that will complete their development over the course of the summer (Fig. 1C). Despite slight variations in color and size, we did not find significant morphological differences between larvae within or between ponds.

Total length and body length of embryos and larvae is plotted against their stages in Figure 9A. Early stages (cleavage, blastula, and gastrula; i.e., Stages 1-12) involve mostly morphological differentiation, but no growth. However, when hatching occurs, total and body length increase due to prevalent growth and further differentiation. Consequently, morphological variation increases during Stages 21-25. During feeding stages (Stages 2740 ), size can vary considerably among individuals and size ranges for different stages often overlap. Tadpole variation in size at these stages might be related to spatial and temporal variables (i.e., precipitation, food availability,
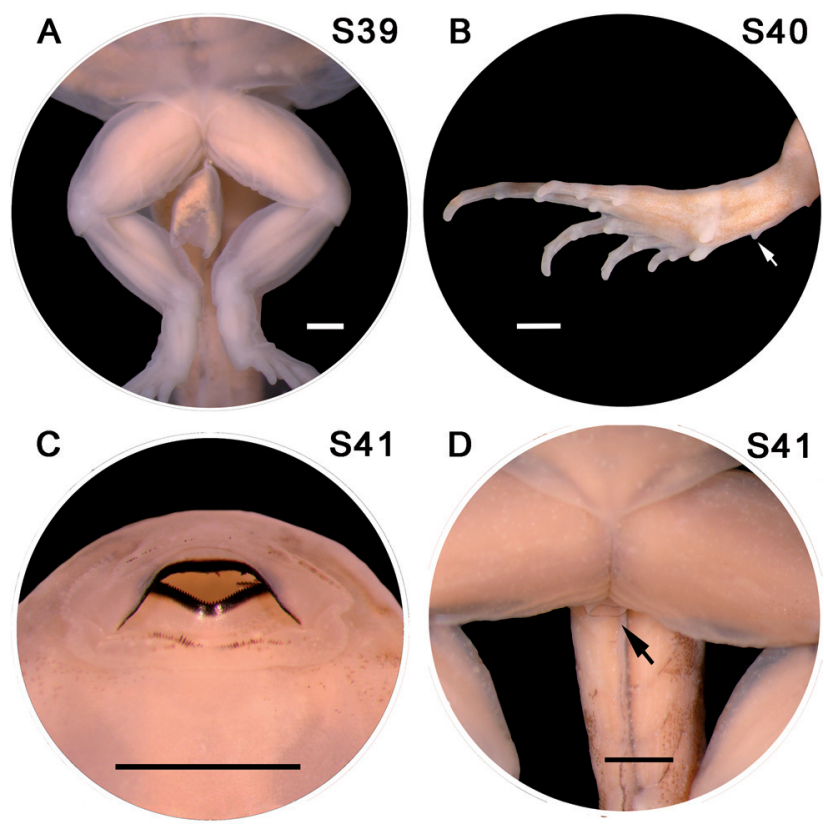

Figure 7. Physalaemus biligonigerus in Stages 39-41. (A) Hind limbs united proximally in the midventral line, constricting the anal tube; (B) hind limb at Stage 40 with tarsal (arrow) and prominent metatarsal and digital subarticular tubercles; (C) oral disc prior to metamorphosis showing absence of keratinized teeth; (D) anal opening (note that skin of the anal tube remains as a vestige attached to the ventral fin; arrow). Stages indicated by codes S39-S41. Scale bars $=1 \mathrm{~mm}$. 


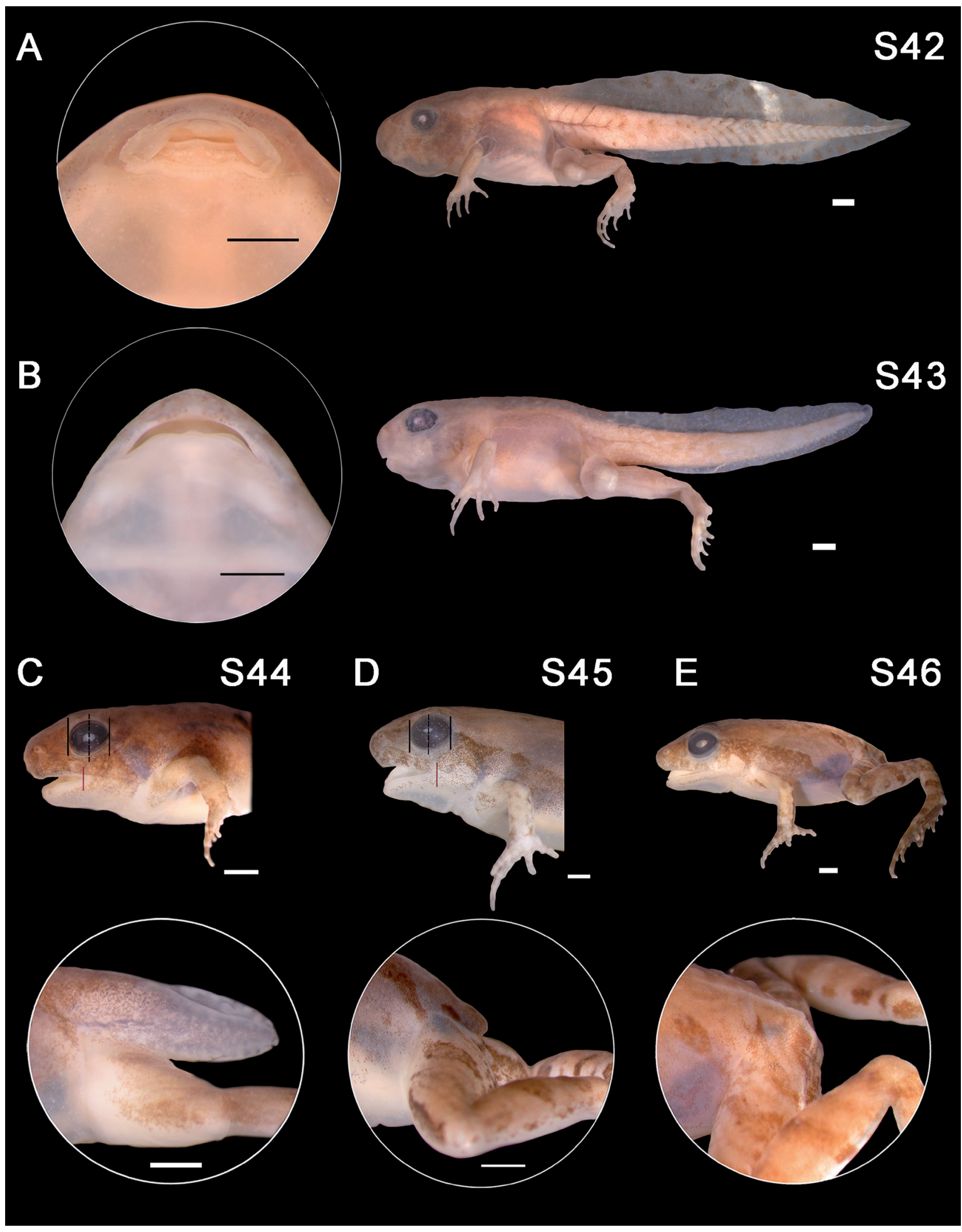

Figure 8. Metamorphosis of Physalaemus biligonigerus. (A) Oral disc and lateral view of whole organism in Stage 42; (B) Mouth and lateral view of metamorphic individual in Stage 43; (C) Lateral view of anterior part of body of metamorphic individual in Stage 44 with mouth commissure prior to anterior half of the eye and detail of tail resorption; (D) Lateral view of anterior part of the body of metamorphic individual in Stage 45 with mouth commissure exceeding anterior half of eye and tail bud; (E) Stage 46, representing froglet morphology. Stages indicated by codes S42-S46. Scale bars $=1 \mathrm{~mm}$. 


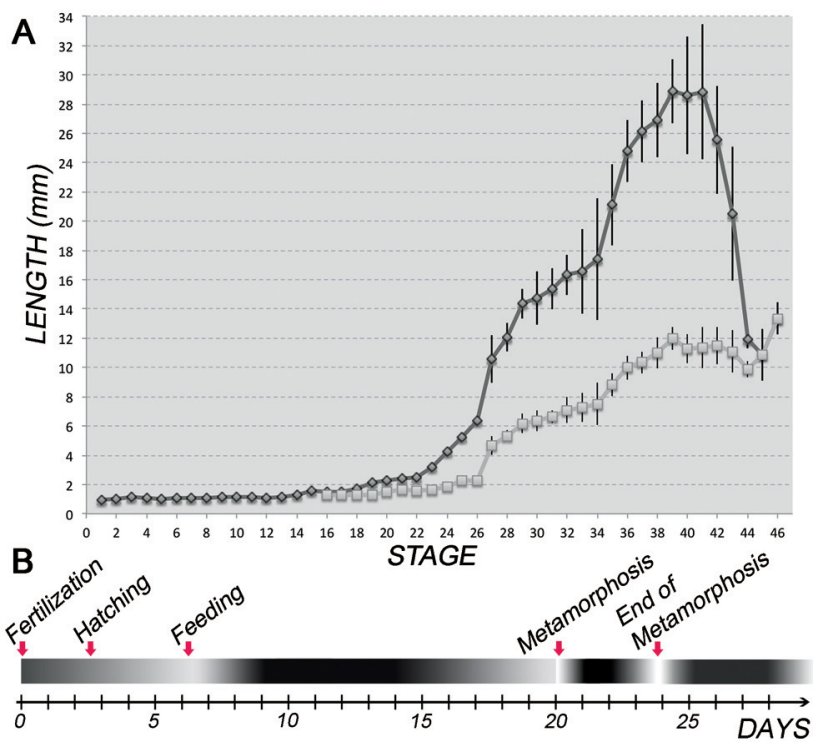

Figure 9. (A) Variation of total length and body length during the complete ontogenesis of Physalaemus biligonigerus. From Stage 27 up to Stage 40 there is approximately constant growth. During metamorphosis, total length decreases due to tail resorption; (B) schematic representation of embryonic and larval development of $P$. biligonigerus through time.

temperature, pond duration). Larval growth increases until Stage 39 when total length reaches its maximum (Fig. 9A). Despite the overall shortening during metamorphosis due to tail resorption, body length remains approximately constant. Complete development from fertilization to the end of metamorphosis occurs in 20-24 d (Fig. 9B). The first stages from fertilization to hatching occur rapidly in $2.5 \mathrm{~d}$ on average. The period from feeding stages to the onset of metamorphosis lasts about $16 \mathrm{~d}$, while metamorphosis encompasses a brief period of $4 \mathrm{~d}$ (Fig. 9B).

\section{DISCUSSION}

In the present study, we divided embryonic and larval development of Physalaemus biligonigerus into 46 stages. External morphological changes used as criteria for staging fertilization, cleavage, gastrulation, and neurulation (Stages 1-15) were the same as those proposed by Shumway (1940) and Nieuwkoop and Faber (1994). In contrast, unlike the criteria based on characters of the living individuals proposed by Limbaugh and Volpe (1957) and synthesized by Gosner (1960), we proposed to distinguish Stages 18-25 on the basis of the number of filaments in external gills (Fig. 3). In the most commonly used tables, these stages are described through physiological characters (e.g., muscular movement, gill circulation, heartbeat), which are impracticable when studying preserved specimens.

Nokhbatolfoghahai and Downie (2008) organized ontogenetic sequences for 21 species belonging to six families based on Gosner (1960). These authors found that external gills varied in number, length, and shape of their secondary filaments (named filaments in this study) among species. Moreover, they showed that external gill development follows a logical sequence, adding filaments consecutively to each gill. In this way, the novel and purely morphological criterion proposed herein-based on external gill morphology - could be used to identify preand post-hatching stages in other anuran species,

In Physalaemus biligonigerus, we distinguished two different morphologies relative to the operculum development. At Stage 25 the operculum starts to develop and is barely visible at the base of the external gills, while at Stage 26 it partially or completely covers the external gills (Fig. 4). Conversely, in Gosner (1960) developmental table describes three states for operculum development; however, those states are short-lived and difficult to observe, so we reduced them to two discernable morphologies for $P$. biligonigerus.

The stages based on limb morphology (Stages 2739; Fig. 6) in Physalaemus biligonigerus are in agreement with the criteria employed in previous published tables (e.g., Limbaugh and Volpe, 1957; Gosner, 1960). During these stages, we observed no major changes in the larval body morphology. For this reason, the hind limb ontogeny provides accurate and unequivocal features for staging this conservative period.

Stage 40 is defined by both the appearance of the tarsal tubercle and the visibility of fibers of the rectus abdominis muscle. The tarsal tubercle is a conspicuous morphological trait of several species of Physalaemus, but it is absent in others (Lynch, 1970; Nascimento et al., 2005; Fig. 7B). Consequently, for those species lacking the tarsal tubercle, the visibility of fibers of the $M$. rectus abdominis defines Stage 40, although interspecific variability in this trait should be tested. Additionally, in P. biligonigerus the anal tube has already been lost in Stage 39. Conversely, in the developmental table proposed by Gosner (1960) the anal tube disappears at Stage 41 just prior to metamorphosis. The timing of disappearance of the anal tube has been described for several anuran species and is highly variable (Fabrezi, 2011). As such, we advise caution when using this trait to stage development.

On the basis of scanning electron micrographs, Zaracho et al. (2003) described oral disc, external gill, adhesive organ, and operculum development for Physalaemus biligonigerus through Gosner Stages 19-25. We noted some differences in comparison with our results. For example, we have found that hatching occurs at Stages 21-22, whereas Zaracho et al. (2003) indicated hatching at Stage 19. This difference might be related to hatching plasticity, which is influenced by rearing conditions, oxygen concentration, temperature, and predator risk, among others. Furthermore, they neglected morphological changes of the gills as a result of the use of Gosner's table and made no ex- 
Table 2. Developmental tables available for leparis characteristics (modified from Fabrezi et al., 2017). ES: embryonic stage; LS: larval stage; DLC: development under laboratory conditions.

\begin{tabular}{lll}
\hline \multicolumn{1}{c}{ Species } & \multicolumn{1}{c}{ Characteristic } & \multicolumn{1}{c}{ Author } \\
\hline Engystomops spp. & $23 \mathrm{ES}, 3 \mathrm{~d}$ & Romero-Carvajal et al. (2009) \\
Engystomops guayaco (Ron et al., 2005) & $23 \mathrm{ES}, 77 \mathrm{~h}, 18-23^{\circ} \mathrm{C}$ & Andrade-Cahueñas (2015) \\
Physalaemus albonotatus (Steindachner, 1864) & $46 \mathrm{ES}$ and LS, DLC & Gómez et al. (2016) \\
Physalaemus nattereri (Steindachner, 1863) & $46 \mathrm{ES}$ and LS, 32 d & Vizzoto (1967) \\
Pleurodema bibroni Tschudi, 1838 & $12 \mathrm{ES}, \mathrm{DLC}, 195 \mathrm{~h}, 18^{\circ} \mathrm{C}$ & Izquierdo and Pereda (1964) \\
Pleurodema brachyops (Cope, 1869) & $25 \mathrm{ES}, \mathrm{DLC}, 72 \mathrm{~h}$ & León-Ochoa and Donoso-Barros (1969) \\
\hline
\end{tabular}

plicit reference to developmental timing. As such, incorporating changes in the gill morphology provides a more reliable staging system, especially when working with preserved specimens.

The main differences between larvae of the species of the Physalaemus biligonigerus group ( $P$. biligonigerus, P. marmoratus, $P$. santafecinus, $P$. riograndensis) are found in their oral disc morphologies. The presence of two lower labial tooth rows is known only in these four species, so it might be a synapomorphy of this species group (Lourenço et al., 2015). Additionally, there is a complete row of marginal papillae on the lower labium in P. biligonigerus and $P$. santafecinus, and there are two ventrolateral gaps in the lower labium in the remaining two species (Perotti and Céspedez, 1999; Nomura et al., 2003; Borteiro and Kolenc, 2007). Interestingly, variations within this configuration have been described previously among $P$. biligonigerus populations. Fernández and Fernández (1921) mentioned that tadpoles sampled in Santa Fe, Argentina, have a labial tooth row formula 2 (2)/2. However, we observed a narrow gap in P1 in the larvae examined in this study. This is in agreement with the description of Borteiro and Kolenc (2007) and Schulze et al. (2015) for populations in Uruguay and Bolivia, respectively. Another feature described by Schulze et al. (2015) and observed in their figure is the partly fragmented P2 keratodont row. Moreover, they described the presence of submarginal papillae laterally, absent in the descriptions of Fernandez and Fernández (1921), Borteiro and Kolenc (2007), as well as in the present work. The variation in the absence/ presence of gap in $\mathrm{P} 1$ seems to be an alternative state of a polymorphic character. The fragmented P2 keratodont row and the presence of submarginal papillae can result from developmental alterations. Despite the variations detailed above and slight differences in color or body length, tadpole morphology of P. biligonigerus is in general highly conservative. This suggests that genetic variability within or even between populations that inhabit different ecoregions in South America is not necessarily translated into meaningful morphological diversity.

At the interspecific level, several aspects of Physalaemus tadpoles are well known (Miranda and Ferreira, 2009; Ruggeri and Weber, 2012; Schulze et al., 2015), but generally the morphology of larval stages and its spatiotem- poral variations are interpreted using the standard table proposed by Gosner (1960). Studies about variation in the oral apparatus suggested important evolutionary changes in oral disc morphogenetic patterns (Vera Candioti et al., 2011). These findings could be enhanced with data on developmental timing supplied by specific developmental tables, which can explain heterochronic variations.

Remarkably, staging tables previously developed for other leiuperines focus on specific ontogenetic periods (particularly the initial phases; Table 2). Moreover, these tables do not provide developmental times and often lack adequate illustrations to distinguish key characters and intraspecific variation. Furthermore, the most widely used staging tables are built for species that are not necessarily widespread or have typical larvae (Shumway, 1940; Taylor and Kollros, 1946; Limbaugh and Volpe, 1957; Nieuwkoop and Faber, 1994). It is also noteworthy that the table proposed by Gosner (1960) is simplified from older ones for Lithobates (previously Rana) pipiens (Schreber, 1782) (Shumway, 1940; Taylor and Kollros, 1946) and for Bufo (now Incilius) valliceps (Limbaugh and Volpe, 1957). Gosner's table is a helpful tool with well-defined characters per stage, but some of the characters are based only on physiological characters of living individuals. In contrast, the developmental table presented here for Physalaemus biligonigerus includes exhaustive descriptions and images for complete developmental phases, as well as data on time and size of each stage. This information can be useful for diverse biological studies (i.e., taxonomic, ecological, biogeographic) and mainly for studying variation among populations in different ecosystems. Moreover, the variation we found in the development of the external gills, operculum, and anal tube of $P$. biligonigerus indicates the relevance of having species-specific developmental tables to interpret the evolution of ontogenies.

Finally, some questions about the reproduction of Physalaemus biligonigerus remain, such as if adults ( $\mathrm{fe}-$ male, male, or both) are able to reproduce more than once per summer season. This and other questions remain unanswered for many Neotropical anuran species. Accordingly, staging of embryos and larvae represents the first step to understand evolutionary consequences of ephemeral water bodies on life cycles of the anuran species that inhabit the semiarid Chacoan environments. 


\section{ACKNOWLEDGMENTS}

We are grateful to Richard Wassersug who provided useful suggestions and kindly helped with English grammar and Agustín Scanferla for his critical reading of an early version of the manuscript. This research received financial support from Agencia Nacional de Promoción Científica y Técnica (PICT 2014-0510) and Consejo Nacional de Investigaciones Científicas y Técnicas (PIP 497).

\section{REFERENCES}

Andrade-Cahueñas C. 2015. Desarrollo y somitogénesis de Engystomops guayaco (Anura: Leptodactylidae) desde el huevo fecundado hasta la eclosión del renacuajo. Undergraduate thesis, Pontificia Universidad Católica del Ecuador, Ecuador.

Barrio A. 1965. Afinidades del canto nupcial de las especies cavícolas del género Leptodactylus (Anura - Leptodactylidae). Physis 25:401410.

Borteiro C., Kolenc F. 2007. Redescription of the tadpoles of three species of frogs from Uruguay (Amphibia: Anura: Leiuperidae and Leptodactylidae), with notes on natural history. Zootaxa 1638:1-20. DOI

Cei J.M. 1980. Amphibians of Argentina. Monitore Zoologico Italiano, Monographia 2. Universita degli studi, Firenze.

Cope E.D. 1861. Descriptions of new species of the reptilian genera Hyperolius, Liuperus and Tropidodipsas. Proceedings of the Academy of Natural Sciences of Philadelphia 12:517-518.

Cope E.D. 1869. Sixth contribution to the herpetology of tropical America. Proceedings of the Academy of Natural Sciences of Philadelphia 20:305-312.

Daudin F.M. 1802. Histoire Naturelle des Rainettes, des Grenouilles, et des Crapauds. Bertrandert, Libraire Levrault, Paris. DOI

Duellman W.E., Trueb L. 1994. Biology of Amphibians. The Johns Hopkins University Press, Baltimore.

Dünker N., Wake M.H., Olson W.M. 2000. Embryonic and larval development in the caecilian Ichthyophis kohtaoensis (Amphibia, Gymnophiona): a staging table. Journal of Morphology 243:3-34. DOI

Fabrezi M. 2011. Heterochrony in growth and development in anurans from the Chaco of South America. Evolutionary Biology 38:390-411. DOI

Fabrezi M., Quinzio S., Goldberg F.J. 2009. The giant tadpole and delayed metamorphosis of Pseudis platensis Gallardo, 1961 (Anura, Hylidae). Journal of Herpetology 43:228-243. DOI

Fabrezi M., Quinzio S., Goldberg F.J., de Sá R.0. 2012. The development of Dermatonotus muelleri (Anura: Microhylidae: Gastrophryninae). Journal of Herpetology 46:363-380. DOI

Fabrezi M., Quinzio S., Cruz J.C., Chuliver Pereyra M., Manzano A., Abdala V., ... Goldberg F.J. 2017. Forma, tamaño y tiempo en la ontogenia de Anfibios y Reptiles. Cuadernos de Herpetología 31:103126. DOI

Fernández K., Fernández M. 1921. Sobre la biología y reproducción de algunos batracios argentinos. I Cystignathidae. Anales de la Sociedad Científica Argentina 91:97-144.

Fitzinger L.J. 1826. Neue classification der Reptilien nach ihren natürlichen Verwandtschaften nebst einer Verwandtschafts-Tafel und einem Verzeichnisse der Reptilien-Sammlung des K.K. Zoologisch Museum's zu Wien. J.G. Heubner, Vienna. DOI

Frost D.R. 2018. Amphibian Species of the World: an Online Reference. Version 6.0. Accessible at http://research.amnh.org/herpetology/amphibia/index.html.

Gómez M.L., Zaracho V.H., Sandoval M.T. 2016. Desarrollo embrionario-larval y metamorfosis de Physalaemus albonotatus (Anura: Leptodactylidae). Revista Veterinaria 27:21-27.
Gosner K.L. 1960. A simplified table for staging anuran embryos and larvae with notes on identification. Herpetologica 16:183-190.

Hall J.A., Larsen J.H. Jr., Fitzner R.E. 1997. Postembryonic ontogeny of the spadefoot toad, Scaphiopus intermontanus (Anura: Pelobatidae): external morphology. Herpetological Monographs 11:124-178. DOI

Iwasawa H., Yamashita K. 1991. Normal stages of development of a Hynobiid salamander, Hynobius nigrescens Stejneger. Japanese Journal of Herpetology 14:39-62. DOI

Izquierdo L., Pereda J. 1964. Influencia de la temperatura ambiental sobre el desarrollo de Pleurodema bibroni. Archivos de Biología Médica y Experimental 1:141-151.

León-Ochoa J., Donoso-Barros R. 1969. Desarrollo embrionario y metamorfosis de Pleurodema brachyops (Cope) (Salientia, Leptodactylidae). Boletín de la Sociedad de Biología de Concepción 42:355-379.

Limbaugh B.A., Volpe E.P. 1957. Early development of the Gulf Coast toad, Bufo valliceps Wiegmann. American Museum Novitates 1842:1-32.

Lourenço L.B., Targueta C.P., Baldo D., Nascimento J., Garcia P.C.A., Andrade G.V., ... Recco-Pimentel S.M. 2015. Phylogeny of frogs from the genus Physalaemus (Anura, Leptodactylidae) inferred from mitochondrial and nuclear gene sequences. Molecular Phylogenetics and Evolution 92:204-216. DOI

Lynch J.D. 1970. Systematic status of the American Leptodactylid frog genera Engystomops, Eupemphix, and Physalaemus. Copeia 3:488-496. DOI

Milstead W.W. 1960. Frogs of the genus Physalaemus in southern Brazil with the description of a new species. Copeia 1960:83-89. DOI

Miranda N.E.O., Ferreira A. 2009. Morfologia oral interna de larvas do gênero Eupemphix, Physalaemus e Leptodactylus (Amphibia: Anura). Biota Neotropica 9:165-176. DOI

Nascimento L.B., Caramaschi U., Gonçalves Cruz C.A. 2005. Taxonomic review of the species groups of the genus Physalaemus Fitzinger, 1826 with revalidation of the genera Engystomops Jiménezde-la-Espada, 1872 and Eupemphix Steindachner, 1863 (Amphibia, Anura, Leptodactylidae). Arquivos do Museu Nacional, Rio de Janeiro 63:297-320.

Nieuwkoop P.D., Faber J. 1994. Normal table of Xenopus laevis (Daudin). Garland Publishing, New York.

Nokhbatolfoghahai M., Downie J.R. 2008. The external gills of anuran amphibians: comparative morphology and ultrastructure. Journal of Morphology 269:1197-1213. DOI

Nomura F., Rossa-Feres D.C., Prado V.H.M. 2003. The tadpole of Physalaemus fuscomaculatus (Anura: Leptodactylidae), with a description of internal oral morphology. Zootaxa 370:1-8. DOI

Orton G.I. 1953. The systematics of vertebrate larvae. Systematic Zoology 2:63-75. DOI

Perotti M.G., Céspedez J.A. 1999. The tadpole of Physalaemus santafecinus, with comments on buccopharyngeal morphology. Journal of Herpetology 2:312-315. DOI

Pyron R.A., Wiens J.J. 2011. A large-scale phylogeny of Amphibia including over 2,800 species, and a revised classification of extant frogs, salamanders, and caecilians. Molecular Phylogenetics and Evolution 61:543-583.

Reinhardt J.T., Lütken C.F. 1862. Bidrag til Kundskab om Brasiliens Padder og Krybdyr. Förste Afdeling: Padderne og Öglerne. Videnskabelige Meddelelser fra Dansk Naturhistorisk Forening i Kjøbenhavn, Serie 2 3:143-242.

Romero-Carvajal A., Sáenz-Ponce N., Venegas-Ferrín M., Almeida-Reinoso D., Lee C., Bond J., ... del Pino E.M. 2009. Embryogenesis and laboratory maintenance of the foam-nesting túngara frogs, genus Engystomops (= Physalaemus). Developmental Dynamics 238:1444-1454. DOI

Ron S.R., Coloma L.A., Cannatella D.C. 2005. A new, cryptic species of Physalaemus (Anura: Leptodactylidae) from western Ecuador, with comments on the call structure of the P. pustulosus species group. Herpetologica 61:178-198. DOI

Ruggeri J., Weber L.N. 2012. A survey of the internal oral features and external morphology of Physalaemus larvae (Anura, Leptodactylidae). Zootaxa 3200:1-26. DOI 
Sammouri R., Renous S., Exbrayat J.M., Lescure J. 1990. Développement embryonnaire de Typhlonectes compressicaudus (Amphibia, Gymnophiona). Annales des Sciences Naturelles, Zoologie et Biologie Animale 11:135-163.

Schreber H. 1782. Beitrag zur Naturgeschichte der Frösche. Der Naturforscher, Halle 18:182-193.

Schreckenberg G.M., Jacobson A.G. 1975. Normal stages of development of the axolotl, Ambystoma mexicanum. Developmental Biology 42:391-399. DOI

Schulze A., Jansen M., Köhler G. 2015. Tadpole diversity of Bolivia's lowland anuran communities: molecular identification, morphological characterisation, and ecological assignment. Zootaxa 4016:1-111. DOI

Shi D., Boucaut J.C. 1995. The chronological development of the urodele amphibian Pleurodeles waltl (Michah). International Journal of Developmental Biology 39:427-441.

Shumway W. 1940. Stages in the normal development of Rana pipiens I. External form. The Anatomical Record 78:139-147. DOI

Steindachner F. 1863. Über einige neue Batrachier aus den Sammlungen des Wiener Museums. Sitzungsberichte der Kaiserlichen Akademie der Wissenschaften, Mathematisch-Naturwissenschaftliche Classe 48:186-192.

Steindachner F. 1864. Batrachologische Mittheilungen. Verhandlungen des Zoologisch-Botanischen Vereins in Wien 14:239-288.
Taylor A.C., Kollros J.J. 1946. Stages in the normal development of Rana pipiens larvae. Anatomical Record 94:7-23. DOI

Tschudi J.J. von. 1838. Classification der Batrachier mit Berücksichtigung der fossilen Thiere dieser Abtheilung der Reptilien. Petitpierre, Neuchâtel. DOI

Vera Candioti F., Haad B., Baldo D., Kolenc F., Borteiro C., Altig R. 2011. Different pathways are involved in the early development of the transient oral apparatus in anuran tadpoles (Anura: Leiuperidae). Biological Journal of the Linnean Society 104:330-345. DOI

Vizotto L.D. 1967. Desenvolvimento de Anuros da Região Norte-Ocidental do Estado de São Paulo. Ph.D. Dissertation, Universidade de São Paulo, Brazil.

Wiegmann A.F.A. 1833. Herpetologischen Beyträge. I. Ueber die mexikanischen Kröten nebst Bemerkungen über ihren verwandte Arten anderer Weltgegenden. Isis von Oken 26:651-662.

Zaracho V.H., Céspedez J.A., Alvarez B.B. 2003. Descripción de caracteres morfológicos en larvas prometamórficas de Physalaemus biligonigerus (Anura, Leptodactylidae). Facena 19:97-108.

Zaracho V.H., Céspedez J.A., Alvarez B.B. 2005. Caracterización de las puestas del género Physalaemus (Anura: Leptodactylidae) en Argentina. Boletín de la Asociación Herpetológica Española 15:100-104.

\section{APPENDIX}

Physalaemus biligonigerus: ARGENTINA: Salta: Departamento Gral. José de San Martín: Hickman: RN 81, IBIGEO-A 679, IBIGEO-A 944, IBIGEO-A 958, IBIGEO-A 959, IBIGEO-A 984, IBIGEO-A 1011, IBIGEO-A 1079, IBIGEO-A 1158, IBIGEO-A 1793; Dragones: RN 81, IBIGEO-A 985; Misión Chaqueña: RP53, IBIGEO-A 957, IBIGEO-A 1795; Campichuelo: RN 34, IBIGEO-A 1043; Embarcación: RN34, IBIGEO-A 1157, IBIGEO-A 1813; Departamento General Güemes: RN 34, IBIGEO-A 1797; Departamento Capital: Lomas de Medeiros, IBIGEO-A 1808-1816. 